\title{
CrimRxiv
}

\section{Making sense of senseless murders: The who, what, when, and where?}

Kylie S. Reale, Eric Beauregard, Julien Chopin, Nathan Wells

Published on: Jul 10, 2021

DOI: $10.21428 / \mathrm{cb} 6 \mathrm{ab} 371.57 \mathrm{a} 21 \mathrm{e} 01$

License: Creative Commons Attribution 4.0 International License(CC-BY 4.0). 
